\title{
PENGARUH DIMENSI KEPERCAYAAN (TRUST) TERHADAP PARTISIPASI (PARTICIPATION) PELANGGAN WULAN RENT CAR
}

\author{
Oleh: \\ Dian Novita ${ }^{1}$ \\ Septian Wulandari ${ }^{2}$ \\ Program Studi Informatika \\ Fakultas Teknik dan Ilmu Komputer \\ Universitas Indraprasta PGRI \\ Email: \\ Dyan.novita21@gmail.com ${ }^{1}$, \\ septian.pmb09@ rocketmail.com ${ }^{2}$
}

\begin{abstract}
ABSTRAK
The aim of this study is the level of customer participation in terms of the dimensions of trust to participation Rental Rental Services on Wulan Car Rental Customers. The sample used as the object of research was 75 customers who used rental services in the Wulan Rent Car with a survey method and regression analysis. The meeting was conducted by asking for a questionnaire from the Wulan rent customers. The instrument contains indicators of trust dimensions, there are capability, virtue, and integrity, as well as participation which is elaborated on questions that meet the Likert Scale. All items of validity of the questionnaire have a corrected value of the total correction item of more than $r$ table of 0.1914 so that 13 items of the questionnaire are suitable for use in research instruments. The reliability test using the value of Cronbach's alpha is 0.896. 13 items of the questionnaire are well categorized and can be a criterion in the research instrument. The conclusion is related to the variables of ability, virtue, and integrity that are significant to the participation of rental services in the Wulan Rent Car, there is no significant effect on the ability and benevolence of the variables on the participation of rental services in the rental car. There is a significant integrity variable to the participation of the car rental in Wulan car rental, and the most dominant variable of this study is integrity with a t-value of 3.203 .
\end{abstract}

Keyword: Participation, Rental Service, Trust 


\section{A. PENDAHULUAN}

Semakin berkembangnya zaman,tentunya berkembang pula segala informasi. Dapat kita ketahui kegiatan apapun sekarang berhubungan dengan kemajuan teknologi yang ada. Di dalam dunia usaha pun seperti itu. Hampir semua pelaku usaha dengan mudah dapat menggunakan kemajuan teknologi dalam menjalankan usahanya. Tapi sebelum kemajuan teknologi, ada satu yang sebenarnya sangat mempengaruhi yaitu kepercayaan.

Dalam dunia usaha, kepercayaan adalah suatu hal yang dianggap sangat penting. Selain itu, kepercayaan juga dapat membantu untuk mencapai hasil yang efisien dalam pertukaran ekonomi ketika asimetri informasi hadir (Binzel \& Fehr, 2013). Sedangkan, suatu tingkat kepercayaan seorang pembeli dapat mempengaruhi persepsi resiko suatu transaksi, juga mutu produk sangat berpengaruh terhadap persepsi dari resiko transaksi(Fitdiarini, 2015).Karena dari suatu kepercayaan itulah, maka akan timbul suatu tindakan lanjutan.Seperti yang dikemukakan (Jati Ariwibowo \& Nugroho, 2013)trust merupakan suatu pondasi dari sebuah usaha. Sehingga, transaksi usaha antara penyedia jasa dan konsumenakan terjalin dengan baik dan menumbuhkan kepercayaan antara satu dengan lainnya. Trust, tidak terbentuk dengan sendirinya. Namun, harus dibangun secara bertahap. Oleh karena itu, dapat disimpulkan bahwa kepercayaan adalah sebuah aset yang perlu dimiliki dalam membangun sebuah awal usaha.

Terdapat beberapa peluang usaha yang dapat dimanfaatkan dalam mengatasi permasalahan transportasi di masyarakat. Salah satunya yaitu denganmenggeluti usaha penyewaan rental mobil. Jasa rental atau penyewaan mobil adalah salah satu usaha yang menguntungkan atau menjanjikan, hal itu dikarenakanbanyaknya jenis kendaraan sehinggaindividual maupun badan usaha dapat membuka bisnis penyewaan mobil(Joko Tri Cahyono, 2014). Salah satu faktor memilih usaha rental mobil adalah mahalnya harga kendaraan pribadi sehingga jika konsumeningin berpergian jauh maka konsumen tersebut dapat dengan mudah menggunakan jasa penyewaan mobil(Prince \& Jenifer, M, et, 2016). Disamping itu, perawatan, asuransi, serta lahan untuk parkir menjadisuatu permasalahan bagi sebagian orang untuk mempunyai kendaraan pribadi. Selain dianggap lebih efisien, persyaratan untuk meminjam atau menyewa mobil tergolong cukup mudahyaitu konsumen harus melengkapi beberapa dokumen yang telah ditentukan oleh pihak jasa rental mobil (Abdullah \& Erliana, 2012).

Selain kepercayaan (trust), partisipasi (participation) konsumen dari sebuah usaha juga sangat berpengaruh. Dengan adanya jaminan dokumen sebagai salah satu syarat dalam penyewaan kendaraan sehingga konsumen merasa mendapat jaminan keamanan dalam bertransaksi (Setyoparwati, 2019). Disamping itu, dari pihak penyedia jasa sewa kendaraan juga menjadi aman jika konsumen melengkapi dokumen yang diminta. Sehingga, partisipasi dalam usaha rental mobil akan semakin meningkat. Sebaliknya, Tentunya diimbangi dengan komunikasi yang baik antara kedua belah pihak. Jika kenyataan melebihi suatu harapan seorang pelanggan, maka tingkat partisipasi menimbulkan kepuasan pada diri seorang pelanggan tersebut (Laksmidewi, 2014). Untuk mendapat gambaran 
mengenai pengaruh trust terhadap participation maka pada penelitian ini dilakukan pengaruh dimensi kepercayaan terhadap partisipasi yang dilakukan dengan menguji menggunakan regresi dengan bantuan SPSS. Terdapat penelitian terdahulu yang sejenis dan berkaitan dengan pengaruh ability, benevolence, dan integrity terhadap partisipasi e-commerce yang telah dilakukan oleh Settyoparwati pada tahun 2019. Penelitian tersebut menghasilkan sebuah kesimpulan bahwa variable ability tidak berpengaruh signifikan dan negative terhadap partisipasi ecommerce (Setyoparwati, 2019). Namun, pada penelitian ini objek yang diteliti merupakan konsumen di Wulan Rent Car.

\section{B. KAJIAN PUSTAKA}

\section{Kepercayaan (Trust)}

Kepercayaan bisa menjadi sebuah kunci keberhasilan dalam sebuah usaha. Kepercayaan sangat dibutuhkan dalam rangka menjalin hubungan interpersonal dan melakukan adaptasi. Dengan adanya rasa kepercayaan dari seorang calon pembeli, akan mempengaruhi apakan calon pembeli itu akan melakukan pembelian produk atau tidak.

Kepercayaan (trust) merupakan salah satu dasar yang mempengaruhi pelanggan dalam bertransaksi di media internet (Setyoparwati, 2019). Kepercayaan merupakan suatu faktor yang sangat penting dalam memulai sebuah usaha dan menjalin hubungan kerjasama dalam jangkawaktu yang lama (Piarna \& Apandi, 2018). Jadi dapat disimpulkan Trust suatu kemauan seseorang untuk dapat percaya dengan tindakan orang lain sehingga menimbulkan harapan kepada orang tersebut. Ketika seseorang berada di lingkungan kerja kemudian mendapatkan kepercayaan maka di dunia bisnis ataupun pada lingkungan sekitar akan menimbulkan sesuatu yang baik. Tetapi, sebaliknya ketika kepercayaan itu hilang maka semuanya akan terasa sulit. Berikut ada beberapa faktor yang dapat dilakukan untuk memulai sebuah usaha dan menjalin hubungan kerjasama untuk mempertahankan kepercayaan, sebagai berikut:

a. Kredibilitas

Kredibilitas adalah factor yang harus diperhatikan, karena semakin bagus kualitas dan kapasitas suatu bisnis yang sesuai dengan bidangnya, maka akan semakin bagus juga kredibelnya di mata konsumen.

b. Kedekatan

Kedekatan adalah aspek yang harus dimiliki sebuah perusahaan. Karena tanpa adanya kedekatan kita dengan para konsumen kita, tidak akan dapat terjalin komunikasi yang baik. Dari kedekatan yang sudah terjalin akan juga menimbulkan kenyamanan antara satu sama lain.

c. Reliabilitas

Reliabilitas atau keandalan adalah suatu faktor dimana seorang penjual dapat memenuhi segala kebutuhan dan sesuai dengan harapan konsumennya. 
Dengan demikian sebegitu pentingnya arti dari suatu kepercayaan, karena kepercayaan perlu di bangun dan di bina dengan baik. Bukan datang secara tiba tiba. Banyak orang yang dengan mudah untuk mendapatkan kepercayaan dari sesorang, tetapi belum tentu dapat menjaganya dengan baik.

\section{Dimensi Trust}

Menurut (Wong, 2017) ada tiga factor yang mempengaruhi terbentuknya suatu kepercayaan sebagai berikut: kemampuan (ability), kebaikan hati (benevolence), dan integritas (integrity). Penjelasan ketiga faktor tersebutadalah sebagai berikut:

a. Kemampuan (Ability).Pada faktor ini, seorang penjual atau pengusaha harus menguasai karakteristik wilayah usahanya. Hal itu ditandai dengan kemampuan dalam menyediakan serta melayani, dan memprioritaskan pelanggan dari pihak luar. Artinya bahwa pelanggan mendapatkan jaminan kepuasan dan tingkat keamanan dari seorang penyedia jasa pada saat melakukan transaksi.

b. Kebaikan hati (Benevolence).Kebaikan hati adalah suatu keinginan penjual dalam memnuhi kebutuhan konsumen sehingga kana menimbulkan suatu kepuasan. Keuntungan yang didapatkan oleh penjual dapat ditingkatkan, namun juga tidak mengesampingkan kepuasan konsumen. Penjual tidak hanya mengejar keuntungan yang tinggi, tetapi juga harus mempunyai perhatian yang baik untuk menimbulkan kepuasan konsumen.

c. Integritas (Integrity).Integritas erat kaitannya dengan perilaku penyedia jasa dalam menjalani usahanya. Kemampuan yang diinformasikan kepada konsumen sesuai dengan keadaan yang sebenarnya. Kualitas dan kuantitas jasa yang diberikan dapat menimbulkan suatu kepuasan.

\section{Partisipasi (Participation)}

Partisipasi bukan hanya melibatkan diri secara fisik, melainkan berhubungan dengan orang lain sehingga menimbulkan rasa tanggung jawab dalam kelompok masyarakat.Partisipasi dalam bidang ekonomi, seperti penyedia jasa maupun konsumen, memiliki berbagai potensi keuntungan. Konsumen memperoleh akses yang nyaman dan penyedia jasa dapat memperoleh manfaat di bidang ekonomi. Partisipasi menawarkan berbagai kesempatan dalam memperkuat suatu usaha untuk lingkungan sekitar (Hsiao, Schoenebeck, Moser, \& Dillahunt, 2018). Sedangkan, partisipasi pelanggan merupakan kemauan pelanggan dalam memberikan arahan yang tepat untuk membangun usaha dalam memberikan pelayanan yang terbaik (Jatmiko, 2013). Dengan demikian, partisipasi adalah kemamuan seseorang dalam melibatkan diri sehingga menghasilkan suatu keberhasilan dalam banyak hal. Partisipasi berfungsi sebagai suatu kemitraan (partnership) dalam pembangunan.

Menurut (Wong, 2017), Partisipasi adalah keterlibatan seseorang dalam suatu kegiatan tertentu.Dalam konteks bisnis rental mobil, partisipasi diukur 
dengan banyaknya konsumen yang menggunakan jasa rental mobil di Wulan Rent Car.

Partisipasi pelanggan bukanlah sebuah tujuan pasti melainkan sebuah perjalanan karena strategi ini tidak akan berhenti dan akan terus berkembang seiring berkembangnya industri di sekitar Anda. Dengarkan kemauan, komplain, dan saran dari konsumen agar Anda mendapatkan langkah yang tepat untuk meningkatkan suatu kepercayaan konsumen terhadap brand Anda. Pengusaha yang dapat mengatasi permintaan konsumen akan lebih mudah untuk mendapatkan pelanggan yang setia.Jika pelanggan menyukai produk Anda, maka mereka akan langsung menggunakan jasa Anda dibandingkan dengan jasa di tempat lainnya. Ketika mereka sudah menjadi pelanggan yang setia, mereka akan dengan mudah membantu mempromosikan jasa Anda ke orang lain.

\section{METODE PENELITIAN}

Penelitian ini merupakan penelitian yang diambil dari hasil survei yang artinya sampel yang digunakan diambil secara langsung dari populasi. Populasi yang digunakan dalam penelitian ini adalah perusahaan jasa rental mobil yang bernama Wulan Rent Car yang memiliki 3 cabang. Sedangkan, sampel dalam penelitian ini adalah konsumen dari Wulan Rent Car yang telah menggunakan jasa rental mobil di Wulan Rent Car. Jumlah sampel yang digunakan adalah sebanyak 75 sampel dengan teknik sampling adalah random sampling. Teknik simple random samplingmerupakan teknik dalam pengambilan sampel dari jumlah populasi yang diambil secara acak tanpa memperhatikan tingkat atau strata pada populasi tersebut (Foster, 2018). Teknik pengumpulan data dalam penelitian ini adalah dengan menyebarkan angket atau kuesioner kepada konsumen Wulan Rent Car sedangkan instrumen pada penelitian ini dalah angket yang berisi pertanyaan-pertanyaan untuk dijawab oleh konsumen. Instrumen tersebut berisi indikator dimensi trust yaitu ability, benevolence, dan integrity, serta participation yang dijabarkan dalam pertanyaan-pertanyaan yang memenuhi Skala Likert. Uji coba instrument dilakukan dengan uji validitas serta uji reliabilitas.Uji Validitas merupakan ukuran yang digunakan untuk menunjukkan seberapa jauh pengukur instrumen dalam mengukur objek yang ingin diukur (Triana \& Oktavianto, 2013). Dengan kata lain, uji validitas dimaksudkan untuk mengetahui apakah instrumen pada penelitian ini mampu benar-benar mengukur objek-objek yang akan diukur.Sehingga, uji validitas yang dilakukan dengan menggunakan teknik korelasi product moment, dengan menggunakan SPSS diperoleh bahwa semua butir angket memiliki nilai corrected item-total correction lebih dari $r$ tabel 0,1914 sehingga 13 butir angket layak untuk dijadikan instrumen penelitian.

Uji reliabilitas merupakansuatu tingkatan atau pengujian yang menerangkan bahwa hasil penelitian, pengujian, maupun pengukuran menunjukkan hasil yang sama ataupun konsisten (Puspitawati \& Herawati, 2018). Uji reliabilitas ini digunakan untuk mengukur tingkat konsistensi suatu instrument penelitian. Uji reliabilitas pada penelitian ini menggunakan conbarch's alpha dan diperoleh nilai 
0,896 artinya 13 butir angket dikategorikan baik dan dapat menjadi tolak ukur dalam instrumen penelitian.

Jenis penelitian yang digunakan adalah penelitian assosiatif dengan unit yang dianalisis adalah konsumen perusahaan Wulan Rent Car. Penelitian assosiatif adalah penelitian yang memiliki tujuan untuk mengetahui seberapa besar hubungan antara dua variabel atau lebih (Jati Ariwibowo \& Nugroho, 2013). Penelitian asosiatif merupakan penelitian yang memiliki bentuk seperti hubungan sebab akibat yang memiliki salah satu dari penelitian eksplanasi dan memiliki tujuan menerangkan fungsi dari variabel-variabel yang akan diteliti serta hubungannya antara variabel satu dengan variabel lain (Asiati, 2019). Pengertian assosiatif ini memiliki tujuan untuk mengetahui apakah terdapat pengaruh faktor dimensi trust dengan indikatornya adalah ability $\left(X_{1}\right)$, benevolence $\left(X_{2}\right)$, dan integrity $\left(X_{3}\right)$ terhadap participation $(Y)$ pelanggan jasa rental. Analisis data adalah salah satu cara yang dapatdigunakan pada penelitian untuk mengetahui apakah variabel tertentu mempengaruhi variabel yang lain, sehingga data yang dikumpulkandapat dianalisa dan dapat dijadikan dasar dalam pengambilan kesimpulan. Analisis data yang digunakan pada penelitian ini adalah Analisis Regresi Linier Berganda dengan rumusan sebagai berikut:

$$
Y=a+b_{1} X_{1}+b_{2} X_{2}+b_{3} X_{3}+e
$$

Dimana:

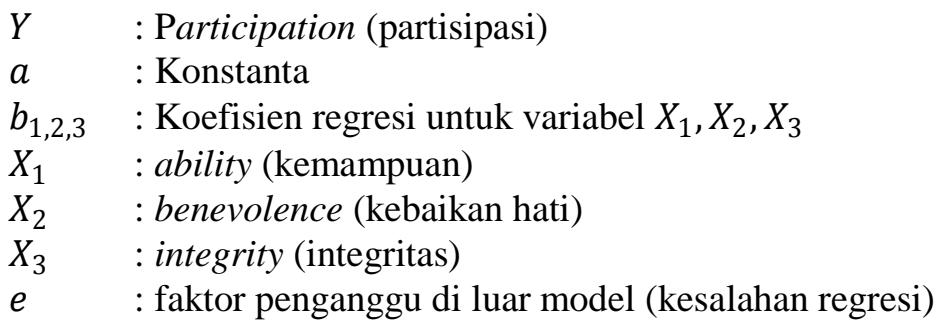

\section{Uji Asumsi Klasik}

\section{a. Uji Normalitas}

Sebaran data yang akan dianalisis diuji terlebih dahulu apakah asumsi normalitas terpenuhi. Data yang baik untuk membuktikan suatu penelitian adalah data tersebut memiliki distribusi normal. Uji normalitas dapat dilakukan dengan melihat beberapa gambar dari histogram suatu data atau dilakukan dengan metode statistik. Uji normalitas yang digunakan dalam penelitian ini yaitu dengan menggunakan one-sample Komologrov-Smirnov dan Shapiro wilk, serta normal probability menggunakan program SPSS.

\section{b. Uji Linearitas}

Uji Linearitas yang dilakukan dalam penelitian ini memiliki tujuan dalam mengetahui apakah ketiga variabel yang digunakan memiliki hubungan secara linear ataupun tidak linier secara signifikan. Uji linearitas dilakukan untuk dapat melihat bagaimana variabel $\left(X_{1}, X_{2}, X_{3}\right)$ mempengaruhi variabel $(Y)$, baik itu pengaruh berbanding lurus maupun berbanding terbalik. Pada penelitian ini, 
penulis melakukan uji linieritas yang digunakan dalam penelitian ini menggunakan bantuan program SPSS 20.

Dasar pengambilan keputusan dengan melihat angka probabilitas, yaitu: (a) Probabilitas Sig. $>0,05$, berarti tidak terdapat perbedaan kelinieran antara variabel independen (variabel bebas) dengan variabel dependen (variabel terikat). (b) Probabilitas Sig. $<0,05$, berarti terdapat perbedaan kelinieran antara variabel

c. Uji Multikolinearitas

Suatu model regresi dikatakan bebas dari multikolinearitas jika mempunyai nilai VIF disekitar angka 1 dan mempunyai angka tolerance mendekati 1. Dimana, tolerance $=1 /$ VIF atau VIF $=1$ /tolerance $($ Maspufah, 2019).

\section{d. Uji Heterokedastisitas}

Uji Heterokedastisitas dilakukan untuk mengetahui apakah di dalam model regresi terdapat perbedaan varian dari residual antara satu pengamatan dengan pengamatan lainnya. Artinya, apabila varian yang dihasilkan dari residual dari satu pengamatan yang dilakukan ke pengamatan lainnya tetap. Uji pada heterokedastisitas menggunakan Scatter Plot. Dalam Sactter Plot apabila terdapat pola yang tidak teratur, maka model regresi yang diuji bebas dari masalah homoskedastisitas, sebaliknya apabila varian tidak sama maka dikatakan heterokedastisitas.

\section{Uji Hipotesis}

\section{a. Uji F}

Uji F adakah suatupengujian dalam statistik yang memberikan informasimengenai semua variabel bebas yang digunakan dapat memberikan pengaruh secara bersamaan terhadap variable terikat.

$H_{0}=0$, artinya tidak terdapat pengaruh yang signifikan dan positif dari variabel bebas secara stimulant terhadap variabel terikat

$H_{1} \neq 0, \quad$ artinya terdapat pengaruh yang signifikan dan positif dari variabel bebas secara stimulant terhadap variabel terikat

Pengujian hipotesis digunakan dengan uji statistik $F$ dengan kriteria pengambilan keputusan sebagai yaitu membandingkan hasil nilai $\mathrm{F}$ hitung dengan hasil nilai $\mathrm{F}$ pada tabel. Jika nilai $\mathrm{F}_{\text {hitung }}>\mathrm{F}_{\text {tabel }}$ artinya $H_{0}$ ditolak dan menerima $H_{1}$.

\section{b. Uji t}

Uji t dilakukan untuk mengetahui apakah variabel bebas secara mandiri memberi pengaruh terhadap varabel terikat. Pengujian yang dilakukan dalam penelitian ini menggunakan tingkat kepercayaan 0,05. Pengujian hipotesis sebagai berikut:

$H_{0}: \beta_{i}=0, \quad$ artinya tidak memiliki pengaruh yang signifikan dan positif dari variabel bebas terhadap variabel terikat 
$H_{1}: \beta_{i} \neq 0, \quad$ artinya terdapat memiliki pengaruh yang signifikan dan positif dari variabel bebas terhadap variabel terikat

Daerah penerimaan maupun daerah penolakan pada hipotesis dilakukan menggunakan kriteria sebagai berikut:

1. Bila nilai signifikan $\mathrm{t}<0.05$, maka $H_{0}$ ditolak, artinya adanya pengaruh yang signifikan dalam satu variabel bebas terhadap variabel terikat.

2. Apabila nilai signifikansi $\mathrm{t}>0.05$, maka $H_{0}$ diterima, artinya tidak terdapat pengaruh yang signifikan dalam satu variabel bebas terhadap variabel terikat.

c. Analisis Koefisien Determinasi $\left(R^{2}\right)$

Pengukuran presentase pengaruh variabel bebas dalam variabel terikat ditunjukkan oleh koefisien determinasi $\left(R^{2}\right)$. Nilai koefisien determinasi diantara nol dan satu. Jika nilai $\left(R^{2}\right)$ kecil maka kemampuan variabel-variabel bebas (ability, benevolence, dan integrity) dalam menjelaskan variasi variabel terikat (participation) sangat terbatas. Begitu pula sebaliknya, nilai yang mendekati satu berarti variabel-variabel bebas memberikan hampir semua informasi yang di butuhkan untuk memeprediksi variasi variabel terikat (Maspufah, 2019).

\section{HASIL DAN PEMBAHASAN}

Pengujian normalitas dilakukan terhadap residual regresi. Pengujian ini dilakukan menggunakan one-sample Komologrov-Smirnov.

\section{Tabel 1}

One-sample Komologrov-Smirnov

One-Sample Kolmogorov-Smirnov Test

\begin{tabular}{|c|c|c|}
\hline & & $\begin{array}{l}\text { Unstandardiz } \\
\text { ed Residual }\end{array}$ \\
\hline \multicolumn{2}{|l|}{$\bar{N}$} & 75 \\
\hline \multirow{2}{*}{$\begin{array}{l}\text { Normal } \\
\text { Parameters }\end{array}$} & Mean & .0000000 \\
\hline & Std. Deviation & .97329982 \\
\hline \multirow{3}{*}{$\begin{array}{l}\text { Most Extreme } \\
\text { Differences }\end{array}$} & Absolute & .089 \\
\hline & Positive & .060 \\
\hline & Negative & -.089 \\
\hline \multicolumn{2}{|l|}{ Test Statistic } & .089 \\
\hline \multicolumn{2}{|c|}{ Asymp. Sig. (2-tailed) } & $.200^{c, d}$ \\
\hline
\end{tabular}
a. Test distribution is Normal.
b. Calculated from data.
c. Lilliefors Significance Correction.
d. This is a lower bound of the true significance.

Menggunakan one-sample Komologrov-Smirnov dapat diintepretasikan bahwa apabila nilai yang diperoleh di atas 0,05, artinya distribusi data diinterpretasikan sebagai asumsi normalitas, dan apabila nilai yang diperoleh di 
bawah 0,05, artinyadianggap sebagai tidak normal. Berdasarkan hasil yang diperoleh, maka dapat diketahui nilai yang diperoleh adalah 0,200 artinya nilai yang diperoleh diatas 0,05 . Oleh karena itu, dapat disimpulkan bahwa data yang digunakan pada pengujian ini berdistribusi normal.

Setelah diketahui ketiga variabel penelitian berdistribusi normal, maka selanjutnya dilakukan uji linieritas untuk masing-masing variabel bebas terhadap variabel terikat. Uji Linearitas pada penelitian ini bertujuan untuk mengetahui ketiga variabel (ability, benevolence, dan integrity) mempunyai keterkaitan yang linear atau tidak linier. Berikut merupakan tabel uji linearitas ketiga variabel bebas (ability, benevolence, dan integrity) terhadap variabel terikat (participation).

Tabel 2.

Hasil Uji Linearitas pada Variabel $\boldsymbol{X}_{1}$

\begin{tabular}{|c|c|c|c|c|c|c|c|}
\hline \multicolumn{8}{|c|}{ ANOVA Table } \\
\hline & & & $\begin{array}{l}\text { Sum of } \\
\text { Squares }\end{array}$ & df & Mean Square & $\mathrm{F}$ & Sig. \\
\hline \multirow{5}{*}{$\begin{array}{l}\text { PARTICIPATION * } \\
\text { ABILITY }\end{array}$} & \multirow[t]{3}{*}{ Between Groups } & (Combined) & 27.265 & 7 & 3.895 & 3.009 & .008 \\
\hline & & Linearity & 20.399 & 1 & 20.399 & 15.758 & .000 \\
\hline & & $\begin{array}{l}\text { Deviation from } \\
\text { Linearity }\end{array}$ & 6.866 & 6 & 1.144 & .884 & .512 \\
\hline & \multicolumn{2}{|l|}{ Within Groups } & 86.735 & 67 & 1.295 & & \\
\hline & \multicolumn{2}{|l|}{ Total } & 114.000 & 74 & & & \\
\hline
\end{tabular}

Probabilitas untuk nilai Deviation from Linearity Sig. $=0,512>0,05$, artinya tidak terdapat perbedaan kelinearan antara variabel $X_{1}$ dengan $Y$. hal ini menunjukkan bahwa data variabel $X_{1}$ dengan $Y$ linear.

Tabel 3.

Hasil Uji Linearitas pada Variabel $\boldsymbol{X}_{2}$

\begin{tabular}{|c|c|c|c|c|c|c|c|}
\hline \multicolumn{8}{|c|}{ ANOVA Table } \\
\hline & & & $\begin{array}{l}\text { Sum of } \\
\text { Squares }\end{array}$ & df & Mean Square & $\mathrm{F}$ & Sig. \\
\hline \multirow{5}{*}{$\begin{array}{l}\text { PARTICIPATION } * \\
\text { BENEVOLANCE }\end{array}$} & \multirow[t]{3}{*}{ Between Groups } & (Combined) & 32.012 & 4 & 8.003 & 6.833 & .000 \\
\hline & & Linearity & 30.623 & 1 & 30.623 & 26.146 & .000 \\
\hline & & $\begin{array}{l}\text { Deviation from } \\
\text { Linearity }\end{array}$ & 1.389 & 3 & .463 & .395 & .757 \\
\hline & \multicolumn{2}{|l|}{ Within Groups } & 81.988 & 70 & 1.171 & & \\
\hline & \multicolumn{2}{|l|}{ Total } & 114.000 & 74 & & & \\
\hline
\end{tabular}

Probabilitas untuk nilai Deviation from Linearity Sig. $=0,757>0,05$, artinya tidak terdapat perbedaan kelinearan antara variabel $X_{2}$ dengan $Y$. hal ini menunjukkan bahwa data variabel $X_{2}$ dengan $Y$ linear. 
Tabel 4.

Hasil Uji Linearitas pada Variabel $X_{3}$

\begin{tabular}{|c|c|c|c|c|c|c|c|}
\hline \multicolumn{8}{|c|}{ A Table } \\
\hline & & & $\begin{array}{l}\text { Sum of } \\
\text { Squares }\end{array}$ & df & Mean Square & $\mathrm{F}$ & Sig. \\
\hline \multirow{5}{*}{$\begin{array}{l}\text { PARTICIPATION * } \\
\text { INTEGRITY }\end{array}$} & \multirow[t]{3}{*}{ Between Groups } & (Combined) & 40.216 & 4 & 10.054 & 9.538 & .000 \\
\hline & & Linearity & 37.528 & 1 & 37.528 & 35.604 & .000 \\
\hline & & $\begin{array}{l}\text { Deviation from } \\
\text { Linearity }\end{array}$ & 2.688 & 3 & .896 & .850 & .471 \\
\hline & Within Groups & & 73.784 & 70 & 1.054 & & \\
\hline & Total & & 114.000 & 74 & & & \\
\hline
\end{tabular}

Probabilitas untuk nilai Deviation from Linearity Sig. $=0,471>0,05$, artinya tidak terdapat perbedaan kelinearan antara variabel $X_{3}$ dengan $Y$. Sehingga dapat disimpulkan data variabel $X_{3}$ dengan $Y$ linear.

Variabel pada penelitian menunjukkan multikolinearitas apabila dilihat dari nilai VIF (Variance Inflation Factor) yang memiliki nilai tinggi dalam variabelvariabel bebas pada suatu model regresi. Nilai VIF yang lebih besar dari 10 menunjukkan adanya gejala multikolinearitas dalam model regresi (Maspufah, 2019). Hasil pada penelitian ini terdapattiga variabel yang digunakan sebagai variabel bebas model regresi menunjukkan nilai VIF yang cukup kecil yaitu VIF $X_{1}=1,476, X_{2}=1,887, X_{3}=1,666$, hal ini menujukkan bahwa nilainya berada di bawah 10 dan nilai Tollerance $X_{1}=0,677, X_{2}=0,530, X_{3}=0,600$ lebih dari 0,1 . Sehingga, dapat disimpulkan variabel bebas yang diteliti dalam penelitian tidak menunjukkan gejala multikolinearitas.

Pengujian heteroskedastisitas menggunakan Scatter Plot. Jika pengujian tersebut tidak memiliki variabel yang signifikan maka diartikan bahwa tidak terdapat masalah heteroskedastisitas. Hasil pengujian penelitian ini adalah sebagai berikut:

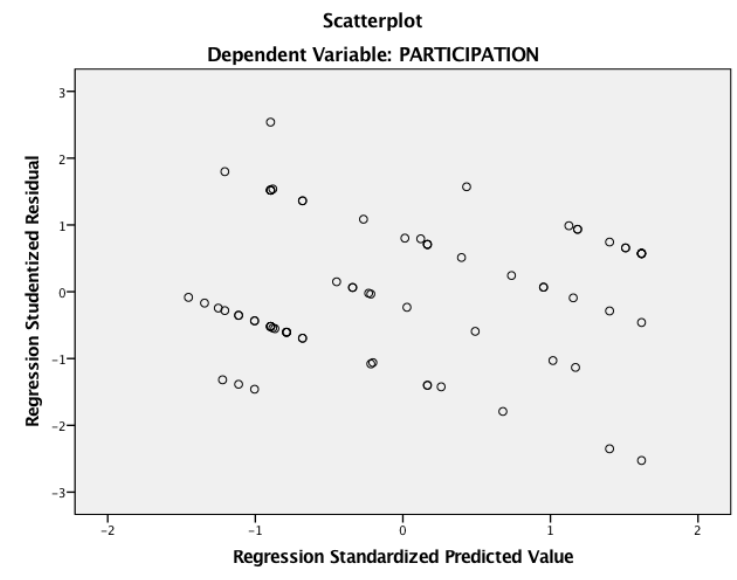

\section{Gambar 1.}

\section{Scatter Plot Uji Heteroskedastisitas}

Pada pengujian heteroskedastisitas menghasilkan bahwa tidak adanya pola yang jelas dari scatter plot di atas, titik-titik menyebar dengan tidak beraturan. Hal ini menunjukkan bahwa model regresi tidak memeilik adanya gejala heteroskedastisitas, artinya tidak ada gangguan yang berarti dalam model regresi 
ini. Sehingga, berdasarkan hasil SPSS diperoleh hasi sebagai berikut:

Tabel 5.

Regresi Linear Berganda

Coefficients $^{a}$

\begin{tabular}{|c|c|c|c|c|c|c|c|c|}
\hline \multirow{2}{*}{\multicolumn{2}{|c|}{ Model }} & \multicolumn{2}{|c|}{ Unstandardized Coefficients } & \multirow{2}{*}{$\begin{array}{c}\begin{array}{c}\text { Standardized } \\
\text { Coefficients }\end{array} \\
\text { Beta }\end{array}$} & \multirow[b]{2}{*}{$\mathrm{t}$} & \multirow[b]{2}{*}{ Sig. } & \multicolumn{2}{|c|}{ Collinearity Statistics } \\
\hline & & B & Std. Error & & & & Tolerance & VIF \\
\hline \multirow[t]{4}{*}{1} & (Constant) & 4.764 & 1.291 & & 3.689 & .000 & & \\
\hline & ABILITY & .083 & .070 & .134 & 1.185 & .240 & .677 & 1.476 \\
\hline & BENEVOLENCE & .189 & .117 & .208 & 1.626 & .108 & .530 & 1.887 \\
\hline & INTEGRITY & .345 & .108 & .385 & 3.203 & .002 & .600 & 1.666 \\
\hline
\end{tabular}

Model persamaan regresi pada penelitian ini dapat dituliskan dalam persamaan regresi Unstandardized coefficient adalah sebagai berikut:

$$
Y=4,764+0,083 X_{1}+0,189 X_{2}+0,345 X_{3}
$$

dari hasil persamaan regresi linear berganda diatas data disimpulkan sebagai berikut:

a. Koefisien ability sebesar 0,083, menyatakan bahwa kenaikan satu nilai ability akan menurunkan participation sebesar 0,083 dan sebaliknya penurunan satu nilai ability akan menaikkan participation sebesar 0,083 dengan asumsi variabel bebas lainnya konstan atau tetap.

b. Koefisien benevolence sebesar 0,189, menyatakan bahwa kenaikan satu nilai benevolence akan menurunkan participation sebesar 0,189 dan sebaliknya penurunan satu nilai benevolence akan menaikkan participation sebesar 0,189 dengan asumsi variabel bebas lainnya konstan atau tetap.

c. Koefisien integrity sebesar 0,345, menyatakan bahwa kenaikan satu nilai integrity akan menurunkan participation sebesar 0,345 dan sebaliknya penurunan satu nilai integrity akan menaikkan participation sebesar 0,345 dengan asumsi variabel bebas lainnya konstan atau tetap.

Berdasarkan Tabel 4, dapat disimpulkan bahwa variabel bebas yang paling berpengaruh terhadap participation adalah variabel integrity dengan koefisien 0,345 .

\section{Pengujian Hipotesis Penelitian}

a. Variabel Ability terhadap Participation Jasa Rental.

Pada hasil uji statistik $\mathrm{t}$ untuk variabelability menunjukkan tingkat signifikan sebesar $0,240>\alpha_{(0,05)}$ maka hipotesis ditolak. Sehingga dapat disimpulkan bahwa variabel ability tidak berpengaruh terhadap participation jasa rental. Variabel ability pada penelitian ini memiliki empat indikator yakni kompetensi, pengalaman, pengetahuan luas, serta pengesahan institusional terhadap participation jasa rental. Dari hasil survei yang telah peneliti lakukan, dapat dilihat bahwa konsumen jasa Wulan Rent Car menyatakan tidak setuju bahwa karyawan Wulan Rent Car telah memiliki ability yang baik dalam 
memberikan pelayanan terhadap konsumennya, sehingga konsumen merasa kurang puas dengan layanan yang mereka dapatkan.

b. Variabel Benevolence terhadap Participation Jasa Rental.

Pada hasil uji statistik t untuk variabelBenevolence menunjukkan tingkat signifikan sebesar $(0,108)>\alpha_{(0,05)}$ maka hipotesis ditolak. Sehingga dapat disimpulkan bahwa variabel benevolence tidak berpengaruh terhadap participation jasa rental. Variabel benevolence yang terdiri dari tiga indikator yakni perhatian, kemauan berbagi, serta dapat diharapkan tidak berpengaruh terhadap participation jasa rental. Hal ini berarti bahwa benevolence yang dilakukan oleh karyawan Wulan Rent Car tidak mampu meningkatkan participation jasa rental. Pada indikator pertanyaan yang diberikan responden konsumen Wulan Rent Car menganggap bahwa perhatian dan kemauan berbagi yang diberikan oleh karyawan Wulan Rent Car kurang sesuai dengan apa yang diharapkan oleh para konsumen Wulan Rent Car.

c. Variabel Integrity terhadap Participation Jasa Rental.

Pada hasil uji statistik t untuk variabelintegrity menunjukkan bahwa tingkat signifikan sebesar $(0,002)<\alpha_{(0,05)}$ maka hipotesis diterima. Sehingga dapat disimpulkan variabel integrity berpengaruh terhadap participation jasa rental. Variabel integrity yang terdiri dari tiga indikator yakni pemenuhan kebutuhan, keterusterangan, serta kehandalan dalam penanganan masalah kendala mobil. Hal ini berarti bahwa integrity yang dilakukan oleh karyawan Wulan Rent Car mampu meningkatkan participation konsumennya. Pada indikator pertanyaan yang diberikan, responden konsumen Wulan Rent Car menganggap bahwa pemenuhan kebutuhan serta keterusterangan, dan kehandalan dalam penanganan mobil yang diberikan oleh karyawan Wulan Rent Car sesuai dengan apa yang diharapkan oleh para konsumen Wulan Rent Car. Penilaian konsumen terhadap karyawan dikarenakan karyawan yang bertugas memiliki pengetahuan yang luas untuk mengatasi masalah yang ada, dan pemenuhan kebutuhan mobil apa saja yang diinginkan konsumen, serta kemampuan karyawan Wulan Rent Car dalam mengatasi masalah yang terjadi.

Berdasarkan hasil SPSS, maka diperoleh uji F sebagai berikut:

Tabel 6.

Uji F

\begin{tabular}{|c|c|c|c|c|c|c|}
\hline \multicolumn{7}{|c|}{ ANOVA $^{a}$} \\
\hline & & $\begin{array}{l}\text { Sum of } \\
\text { Squares }\end{array}$ & df & Mean Square & $\mathrm{F}$ & Sig. \\
\hline 1 & $\begin{array}{l}\text { Regression } \\
\text { Residual } \\
\text { Total }\end{array}$ & $\begin{array}{r}43.899 \\
70.101 \\
114.000\end{array}$ & $\begin{array}{r}3 \\
71 \\
74\end{array}$ & $\begin{array}{r}14.633 \\
.987\end{array}$ & 14.821 & $.000^{5}$ \\
\hline
\end{tabular}

Berdasarkan tabel diatas diperoleh nilai $\mathrm{F}$ hitung sebesar 14,821 dan tingkat signifikan 0,000 dengan tingkat signifikan $0,000<\alpha_{(0,05)}$ maka hipotesis 
diterima dan disimpulkan terdapat pengaruh (ability, benevolence, dan integrity) terhadap participation jasa rental.

\section{Koefisien Determinasi}

Tabel 7.

Koefisien Determinasi

Model Summary ${ }^{\text {b }}$

\begin{tabular}{|l|l|l|r|r|}
\hline Model & $\mathrm{R}$ & $\mathrm{R}$ Square & $\begin{array}{c}\text { Adjusted R } \\
\text { Square }\end{array}$ & $\begin{array}{c}\text { Std. Error of } \\
\text { the Estimate }\end{array}$ \\
\hline 1 & $.621^{\mathrm{a}}$ & .385 & .359 & .99365 \\
\hline
\end{tabular}

a. Predictors: (Constant), INTEGRITY, ABILITY, BENEVOLENCE

b. Dependent Variable: PARTICIPATION

Nilai Adjusted $R$ Square adalah 0,359. Hal ini berarti bahwa 35,90\% participation jasa rental dapat dijelaksan oleh variabel ability, benevolence, dan integrity. Sedangkan, $64,10 \%$ participation jasa rental dipengaruhi oleh variabelvariabel lainnyayang tidak diteliti dalam penelitian ini.

\section{E. SIMPULAN} berikut:

Berdasarkan hasil penelitian yang telah dilakukan, maka kesimpulan sebagai

1. Adanya pengaruh yang signifikan variabel ability, benevolence, dan integrity terhadap participation jasa rental di Wulan Rent Car.

2. Tidak adanya pengaruh yang signifikan variabel ability terhadap participation jasa rental di Wulan Rent Car

3. Tidak adanya pengaruh yang signifikan variabel benevolence terhadap participation jasa rental di Wulan Rent Car

4. Adanya pengaruh yang signifikan variabel integrity terhadap participation jasa rental di Wulan Rent Car.

5. Variabel yang berpengaruh paling dominan dari penelitian yang telah dilakukan adalah integrity dengan besarnya nilai t-hitung adalah 3,203. 


\section{DAFTAR PUSTAKA}

Abdullah, D., \& Erliana, C. I. (2012). Bisnis Rental Mobil Melalui Internet (ECommerce) Menggunakan Algoritma Sha-1 (Sequre Hash Algorithm-1). Journal Speed, 4(2), 38-45.

Asiati, D. I. (2019). Pengaruh Bauran Pemasaran Jasa dan Kepercayaan terhadap pembelian Online. Mbia, 18(3), 1-11. https://doi.org/10.33557/mbia.v18i3.677

Binzel, C., \& Fehr, D. (2013). Social distance and trust: Experimental evidence from a slum in Cairo. Journal of Development Economics, 103(1), 99-106. https://doi.org/10.1016/j.jdeveco.2013.01.009

Fitdiarini, N. (2015). Kepercayaan Pelanggan Untuk Melakukan Online Shopping Dan Dampaknya Terhadap Minat Beli Ulang. Jurnal Ekonomi Dan Bisnis, (3), 256-269.

Foster, B. (2018). Pengaruh Program Kewirausahaan Sosial Terhadap Kepercayaan Merek . Studi Kasus Komunitas Disabilitas Bandung, Indonesia. Jurnal Computech \& Bisnis, 12(1), 101-110.

Hsiao, J. C. Y., Schoenebeck, S., Moser, C., \& Dillahunt, T. R. (2018). The role of demographics, trust, computer self-efficacy, and ease of use in the sharing economy. Proceedings of the 1st ACM SIGCAS Conference on Computing and Sustainable Societies, COMPASS 2018. https://doi.org/10.1145/3209811.3209816

Jati Ariwibowo, D. P., \& Nugroho, M. A. (2013). Pengaruh Trust Dan Perceived of Risk Terhadap Niat Untuk Bertransaksi Menggunakan E-Commerce. Nominal, Barometer Riset Akuntansi Dan Manajemen, 2(1), 11-35. https://doi.org/10.21831/nominal.v2i1.1646

Jatmiko, M. R. (2013). Pengaruh Pengelolaan Masalah Pelanggan, Edukasi PEelanggan dan Partisipasi Pelanggan Terhadap Loyalitas Pelanggan. Jurnal Ilmu Manajemen Dan Akuntasi Terapan (JIMAT), 4(2), 100-108.

Joko Tri Cahyono, S. (2014). Pembuatan Sistem Informasi Rental Mobil Purnama Rent Car Ploso Pacitan Berbasis Web. Pembuatan Sistem Informasi Rental Mobil Purnama Rent Car Ploso Pacitan Berbasis Web, 3 No 1(1), 6.

Laksmidewi, D. (2014). Partisipasi Pelanggan, Aanteseden dan Pengaruhnya Terhadap Kualitas Jasa: Perspektif Service-Dominant Logic. Jurnal Manajemen, 11(2), 22-37.

Maspufah, H. (2019). Analisis Kualitas Pelayanan Terhadap Kepuasan Anggota Perpustakaan STIE Mandala Jember. Journal of Applied Business and Economic Vol., 5(3), 215-229.

Piarna, R., \& Apandi, T. H. (2018). Pengaruh Dimensi Kepercayaan Terhadap Keputusan Bertransaksi Pelanggan E-Commerce Di Indonesia. Jurnal Ilmiah Ilmu Dan Teknologi Rekayasa, 1(1), 29-35. 
https://doi.org/10.31962/jiitr.v1i1.3

Prince, T., \& Jenifer, M, et, A. (2016). Design of Car Rental Management System for Organization, Customers and Car Owners. International Journal of Engineering Trends and Technology, 34(7), 319-321. https://doi.org/10.14445/22315381/ijett-v34p263

Puspitawati, H., \& Herawati, T. (2018). Reliabilitas Dan Validitas Indikator Ketahanan Keluarga Di Indonesia ( Reliability and Validity of Family Resilience Indicators in Indonesia ). Kependudukan Indonesia, 13(1), 1-14.

Setyoparwati, I. C. (2019). Commerce ( Studi Kasus Konsumen E-Commerce di Indonesia ). 8(2), 166-176.

Triana, D., \& Oktavianto, W. O. (2013). Relevansi Kualifikasi Kontraktor Bidang Teknik Sipil Terhadap Kualitas Pekerjaan Proyek Konstruksi Di Provinsi Banten. Jurnal Fondasi, 2(2), 182-190.

Wong, D. (2017). Pengaruh Ability, Benevolence Dan Integrity Terhadap Trust, Serta Implikasinya Terhadap Partisipasi Pelanggan E-Commerce: Studi Kasus Pada Pelanggan E-Commerce Di Ubm. Jurnal Riset Manajemen Dan Bisnis (JRMB) Fakultas Ekonomi UNIAT, 2(2), 155-168. https://doi.org/10.36226/jrmb.v2i2.46 